Article

\title{
Sporulosol, a New Ketal from the Fungus Paraconiothyrium sporulosum
}

\author{
Chen Zhao ${ }^{1}$, Peinan Fu ${ }^{1,2}$, Yang Zhang ${ }^{1}$, Xingzhong Liu ${ }^{3}$, Fengxia Ren ${ }^{1, *}$ and Yongsheng Che ${ }^{1, *}$ \\ 1 State Key Laboratory of Toxicology \& Medical Countermeasures, Beijing Institute of Pharmacology \& \\ Toxicology, Beijing 100850, China; lfyz34304@126.com (C.Z.); \\ fpn1109@aliyun.com (P.F.); zhangyang@bmi.ac.cn (Y.Z.) \\ 2 College of Pharmacy, Nanjing University of Chinese Medicine, Nanjing 210023, China \\ 3 State Key Laboratory of Mycology, Institute of Microbiology, Chinese Academy of Sciences, \\ Beijing 100190, China; liuxz@im.ac.cn \\ * Correspondence: renfx@bmi.ac.cn (F.R.); cheys@im.ac.cn (Y.C.); Tel.: +86-10-6693-2679 (Y.C.)
}

Received: 10 April 2018; Accepted: 22 May 2018; Published: 25 May 2018

check for updates

\begin{abstract}
Sporulosol (1), a new ketal, together with four known compounds, has been isolated from the liquid fermentation cultures of a wetland-soil-derived fungus, Paraconiothyrium sporulosum. Its structure was elucidated primarily by NMR experiments, and was further confirmed by X-ray crystallography. Sporulosol was obtained as a racemic mixture and the resolved two enantiomers racemized immediately after chiral separation. Sporulosol appears to be the first ketal derived from a $6 H$-benzo[c]chromen-6-one and a benzofuranone unit. The compound showed modest cytotoxicity toward the human tumor cell line $\mathrm{T} 24$, with an $\mathrm{IC}_{50}$ value of $18.2 \mu \mathrm{M}$.
\end{abstract}

Keywords: Paraconiothyrium sporulosum; ketal; racemate; cytotoxicity

\section{Introduction}

Fungi are one of the most important sources of new drugs or lead compounds; many important medicines have been discovered directly from fungi or developed based on their secondary metabolites [1], such as the antibiotic penicillin, anti-cholesteremic agent lovastatin, immuno-suppressant cyclosporin A, and the anti-multiple sclerosis fingolimod. Fungal species isolated from the wetland environments have attracted increasing attention due to their ability to produce a variety of bioactive secondary metabolites. Examples include stachybisbins A and B [2], flaviphenalenones A-C, aspulvinones P and Q, methybutyrolactone III [3,4], 5-hydroxymethylasterric acid, 3,5-dichlorosulochrin [4], and isocoumarin glycosides [5]. Based on this consideration, we initiated chemical studies of the wetland-soil-derived fungal species in the genus of Paraconiothyrium, which was reclassified as a separate genus as Paraconiothyrium by Verkley in 2004 [6]. Prior to our chemical studies, a variety of bioactive secondary metabolites were reported from this genus [7-17]. Our chemical investigations of $P$. brasiliense, and P. hawaiiense grown in solid-substrate fermentation cultures have also resulted in the isolation of structurally diverse and biologically active natural products including brasilamides A-N and hawaiinolides A-G [18-22]. During an ongoing search for new bioactive secondary metabolites from the species of this genus, a strain of Paraconiothyrium sporulosum, which was collected at Poyang Lake, Jiangxi Province, People's Republic of China, was subjected to our chemical investigation. A new ketal, named sporulosol (1), was isolated from the liquid fermentation cultures of the fungus, together with four known compounds (2-5; Figure 1). Details of the isolation, structure elucidation, and cytotoxicity of these compounds are reported herein. 


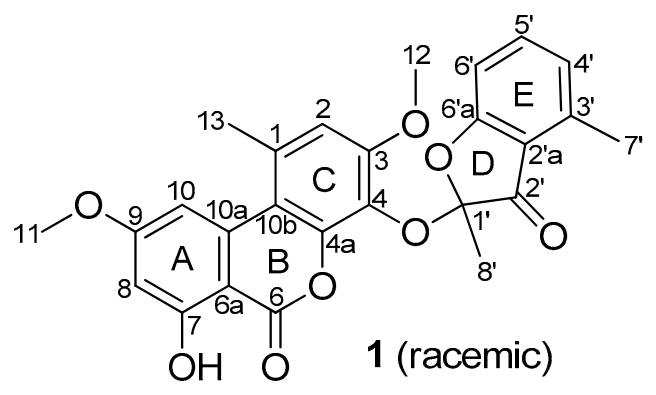

$$
\begin{aligned}
& 2 \mathrm{R}_{1}=\mathrm{OHR}=\mathrm{OH} \\
& 3 \mathrm{R}_{1}=\mathrm{OMeR}=\mathrm{OH} \\
& 4 \mathrm{R}_{1}=\mathrm{OHR} \mathrm{R}_{2}=\mathrm{H}
\end{aligned}
$$<smiles>Cc1ccc(O)c2c1C(=O)C(C)(O)O2</smiles>

Figure 1. Structures of compounds 1-5.

\section{Results and Discussion}

Sporulosol (1) was assigned a molecular formula of $\mathrm{C}_{26} \mathrm{H}_{22} \mathrm{O}_{8}$ (16 degrees of unsaturation) on the basis of high-resolution electrospray ionization mass spectrometry (HRESIMS). Analysis of its nuclear magnetic resonance (NMR) data (Table 1$)$ revealed the presence of an exchangeable proton $\left(\delta_{\mathrm{H}} 11.89\right)$, five methyl groups including two $O$-methyls, one ketal carbon $\left(\delta_{\mathrm{C}} 105.4\right), 18$ aromatic/olefinic carbons with six protonated, one carboxylic carbon $\left(\delta_{C} 164.4\right)$, and one $\alpha, \beta$-unsaturated ketone carbon $\left(\delta_{C} 195.9\right)$. These data accounted for all the NMR resonances and suggested that 1 was a pentacyclic metabolite. The ${ }^{1} \mathrm{H}$ and ${ }^{13} \mathrm{C}$ NMR data of $\mathbf{1}$ (Table 1) revealed structural features that were closely related to the known compounds graphislactone A (3) [23] and 2-hydroxy-2,4-dimethyl-3(2H)-benzofuranone [24], but some chemical shifts for $\mathbf{1}$ were significantly different from those reported for the known compounds, warranting detailed 2D NMR analysis. Interpretation of the NMR data revealed a tetrasubstituted aryl ring (A), with a hydroxy and an O-methyl group attached to C-7 and C-9, respectively, which was confirmed by the HMBC correlations from H-8 to C-6a, C-7, and C-10a; H-10 to C-6a, C-9, and C-10a; OH-7 to C-7 and C-8; and from $\mathrm{H}_{3}-11$ to C-9. Correlations from H-2 to C-1, C-3, $\mathrm{C}-4, \mathrm{C}-4 \mathrm{a}$, and $\mathrm{C}-10 \mathrm{~b} ; \mathrm{H}_{3}-13$ to $\mathrm{C}-1$ and $\mathrm{C}-2$; and from $\mathrm{H}_{3}-12$ to $\mathrm{C}-3$ established the pentasubstituted aryl ring (C). In turn, the HMBC cross peaks from $\mathrm{H}-4^{\prime}$ to $\mathrm{C}-5^{\prime}, \mathrm{C}-6^{\prime}$, and $\mathrm{C}-7^{\prime} ; \mathrm{H}-5^{\prime}$ to $\mathrm{C}-4^{\prime}$ and $\mathrm{C}-6^{\prime}$ a; $\mathrm{H}-6^{\prime}$ to $\mathrm{C}-2^{\prime} \mathrm{a}$ and $\mathrm{C}-5^{\prime}$; and from $\mathrm{H}_{3}-7^{\prime}$ to $\mathrm{C}-2^{\prime} \mathrm{a}, \mathrm{C}-3^{\prime}$, and $\mathrm{C}-4^{\prime}$ enabled junction of the trisubstituted aryl ring (E) with a methyl group attached to $\mathrm{C}-3^{\prime}$. Additional correlations from $\mathrm{H}_{3}-8^{\prime}$ to $\mathrm{C}-1^{\prime}$ and $\mathrm{C}-2^{\prime}$, plus the ${ }^{13} \mathrm{C}$ NMR chemical shifts for $C-2^{\prime} \mathrm{a}\left(\delta_{\mathrm{C}} 117.4\right)$ and C- $6^{\prime}$ a $\left(\delta_{\mathrm{C}} 170.0\right)$, indicated that these three carbons form an $\alpha, \beta$-unsaturated ketone with $C-1^{\prime}$ connected to $C-6^{\prime}$ a via the $C-1^{\prime} / C-6^{\prime}$ a ether linkage. Considering the ${ }^{1} \mathrm{H}$ NMR chemical shift of $\mathrm{OH}-7\left(\delta_{\mathrm{H}} 11.89\right)$ and the unsaturation requirement of $\mathbf{1}$, the carboxylic carbon $\left(\delta_{\mathrm{C}} 164.4\right)$ was connected to $\mathrm{C}-6$, and acylated the $\mathrm{C}-4$ a oxygen to form ring $\mathrm{B}$, while $\mathrm{C}-4$ and $\mathrm{C}-1^{\prime}$ were attached to the only remaining oxygen atom to form an ester linkage. Based on these data, the planar structure of $\mathbf{1}$ was established.

The proposed structure was confirmed by single-crystal X-ray diffraction analysis using $\mathrm{Cu} \mathrm{K} \alpha$ radiation, and a perspective ORTEP plot is shown in Figure 2. Compound $\mathbf{1}$ was found to crystallize as a mixture of $1^{\prime} S$ and $1^{\prime} R$ enantiomers, which explained the low optical rotation value of +1.0 $\left([\alpha]_{\mathrm{D}}^{25} ; c 0.10, \mathrm{MeOH}\right)$ measured for 1 . Subsequently, the racemic mixture was resolved into two enantiomers (1a and $\mathbf{1} \mathbf{b} ; \mathbf{1 : 1}$ ) and decomposition product graphislactone A (3) using chiral stationary phase ( $4.6 \times 250 \mathrm{~mm} ; 4 \%$ 2-propanol in hexanes for $60 \mathrm{~min} ; 0.8 \mathrm{~mL} / \mathrm{min}$ ) (Figure S7). However, the other decomposition product 2-hydroxy-2,4-dimethyl-3(2H)-benzofuranone was not detected during resolution. The absolute configuration of $C-1^{\prime}$ was assigned by the application of Snatzke's chirality rule for cyclopentenones [25], through which the negative or positive Cotton effect for $n \rightarrow \pi$ * transition in the 330-365 nm region of the CD spectrum was used to assign the $1^{\prime} S(\mathbf{1 a})$ and $1^{\prime} R(\mathbf{1 b})$ absolute configurations by HPLC-CD analysis (Figure 3). Analysis of each collected peak for $1^{\prime} S$ (1a) and $1^{\prime} R(\mathbf{1 b})$ revealed the presence of both enantiomers, suggesting the occurrence of spontaneous equilibration. Similarly, the co-isolated known compound, enalin A (5) [26], was also separated into 
two enantiomers $\mathbf{5 a}$ and $\mathbf{5 b}$ in a ratio of $1: 1$, and the resolved enantiomers again racemized immediately after chiral separation (Figure S8). However, subsequent HPLC-CD analysis of 5 was unsuccessful, possibly due to the poor HPLC and CD behavior of the compound (Figure S9). To our knowledge, fungal natural products including isopestacin, pestacin, pestalachloride $\mathrm{A}$, fimetarone $\mathrm{A}$, and arugosins $\mathrm{K}-\mathrm{M}$, have been reported as racemic mixtures of the $S$ and $R$ enantiomers [27-31].

Table 1. NMR data for $\mathbf{1}$ and 2.

\begin{tabular}{|c|c|c|c|c|c|c|}
\hline \multirow{2}{*}{ Pos. } & \multicolumn{3}{|c|}{1} & \multicolumn{3}{|c|}{2} \\
\hline & $\delta_{\mathrm{C}^{a}}$, Mult. & $\delta_{\mathbf{H}}^{b}(J$ in $\mathrm{Hz})$ & НМВС & $\delta_{\mathrm{C}}^{c}$ Mult. & $\delta_{\mathrm{H}}^{d}(J$ in $\mathrm{Hz})$ & НМВС \\
\hline 1 & $134.0, \mathrm{qC}$ & & & $126.6, \mathrm{qC}$ & & \\
\hline 2 & $112.8, \mathrm{CH}$ & $6.90, \mathrm{~s}$ & $1,3,4,4 a, 10 b$ & $112.8, \mathrm{CH}$ & $6.93, \mathrm{~s}$ & $\begin{array}{c}1,3,4,10 a \\
10 b, 12\end{array}$ \\
\hline 3 & $153.8, \mathrm{qC}$ & & & $147.8, \mathrm{qC}$ & & \\
\hline 4 & 128.0, qC & & & $140.6, \mathrm{qC}$ & & \\
\hline $4 a$ & $147.0, \mathrm{qC}$ & & & $138.8, \mathrm{qC}$ & & \\
\hline 6 & 164.4, qC & & & $164.8, \mathrm{qC}$ & & \\
\hline $6 a$ & $98.9, \mathrm{qC}$ & & & $98.2, \mathrm{qC}$ & & \\
\hline 7 & 165.0, qC & & & $165.0, \mathrm{qC}$ & & \\
\hline 8 & $99.5, \mathrm{CH}$ & $6.60, \mathrm{~d}(2.0)$ & $7,6 a, 10 a$ & 101.3, CH & $6.46, \mathrm{~d}(2.0)$ & $6 a, 9,10$ \\
\hline 9 & 166.7, qC & & & 165.3, qC & & \\
\hline 10 & $104.2, \mathrm{CH}$ & $7.28, \mathrm{~d}(2.0)$ & $6 a, 9,10 a$ & $104.9, \mathrm{CH}$ & 7.37, d (2.0) & $6 a, 8,9,10 b$ \\
\hline $10 \mathrm{a}$ & $137.9, \mathrm{qC}$ & & & $132.8, \mathrm{qC}$ & & \\
\hline $10 \mathrm{~b}$ & $111.0, \mathrm{qC}$ & & & $111.2, \mathrm{qC}$ & & \\
\hline 11 & $55.4, \mathrm{CH}_{3}$ & $3.96, \mathrm{~s}$ & 9 & $55.7, \mathrm{CH}_{3}$ & $3.67, \mathrm{~s}$ & 3 \\
\hline 12 & $55.2, \mathrm{CH}_{3}$ & $3.67, \mathrm{~s}$ & 3 & $24.5, \mathrm{CH}_{3}$ & $2.75, \mathrm{~s}$ & $1,2,10,10 \mathrm{a}$ \\
\hline 13 & $24.8, \mathrm{CH}_{3}$ & $2.78, \mathrm{~s}$ & 1,2 & & & \\
\hline $1^{\prime}$ & $105.4, \mathrm{qC}$ & & & & & \\
\hline $2^{\prime}$ & $195.9, \mathrm{qC}$ & & & & & \\
\hline $2^{\prime} \mathrm{a}$ & $117.4, \mathrm{qC}$ & & & & & \\
\hline $3^{\prime}$ & $139.8, \mathrm{qC}$ & & & & & \\
\hline $4^{\prime}$ & $123.8, \mathrm{CH}$ & $6.88, \mathrm{~d}(7.8)$ & $5^{\prime}, 6^{\prime}, 7^{\prime}$ & & & \\
\hline $5^{\prime}$ & $137.7, \mathrm{CH}$ & $7.45, \mathrm{t}(7.8)$ & $4^{\prime}, 6^{\prime} \mathrm{a}$ & & & \\
\hline $6^{\prime}$ & $109.8, \mathrm{CH}$ & $6.72, \mathrm{~d}(7.8)$ & $2^{\prime} a, 5^{\prime}$ & & & \\
\hline $6^{\prime} \mathrm{a}$ & $170.0, \mathrm{qC}$ & & & & & \\
\hline $7^{\prime}$ & 16.7, $\mathrm{CH}_{3}$ & $2.53, \mathrm{~s}$ & $2^{\prime} a, 3^{\prime}, 4^{\prime}$ & & & \\
\hline $8^{\prime}$ & $19.4, \mathrm{CH}_{3}$ & $1.80, \mathrm{~s}$ & $1^{\prime}, 2^{\prime}$ & & & \\
\hline $\mathrm{OH}-7$ & & $11.89, \mathrm{~s}$ & 7,8 & & $11.95, \mathrm{~s}$ & $6 a, 7,8$ \\
\hline
\end{tabular}

${ }^{a}$ Recorded at $100 \mathrm{MHz}$ in acetone- $d_{6} ;{ }^{b}$ Recorded at $400 \mathrm{MHz}$ in acetone- $d_{6} ;{ }^{c}$ Recorded at $150 \mathrm{MHz}$ in acetone- $d_{6}$; ${ }^{d}$ Recorded at $600 \mathrm{MHz}$ in acetone- $d_{6}$.

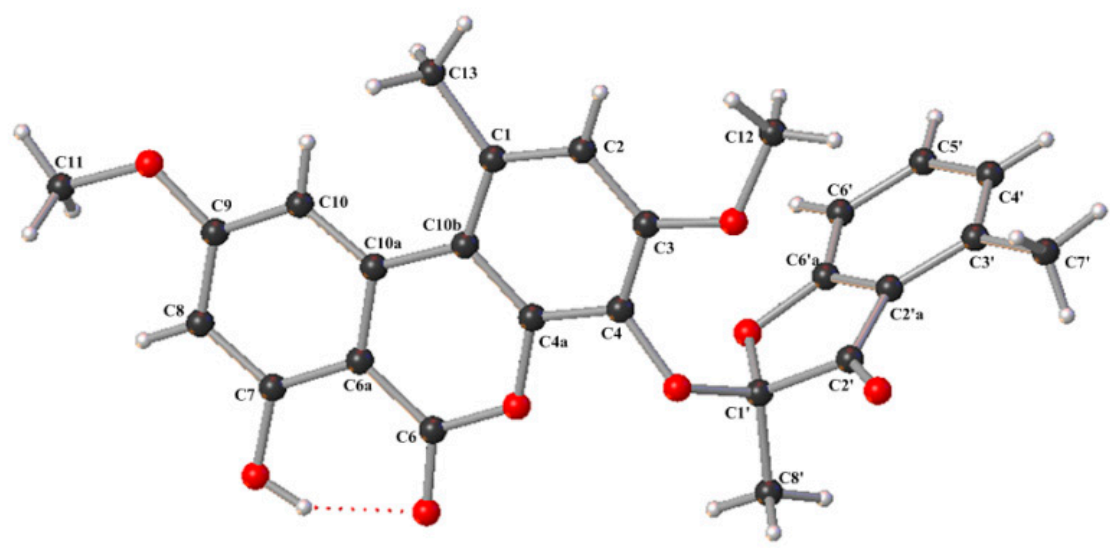

Figure 2. Thermal ellipsoid representation of 1. (Note: A different numbering system is used for the structural data deposited with the CCDC.). 

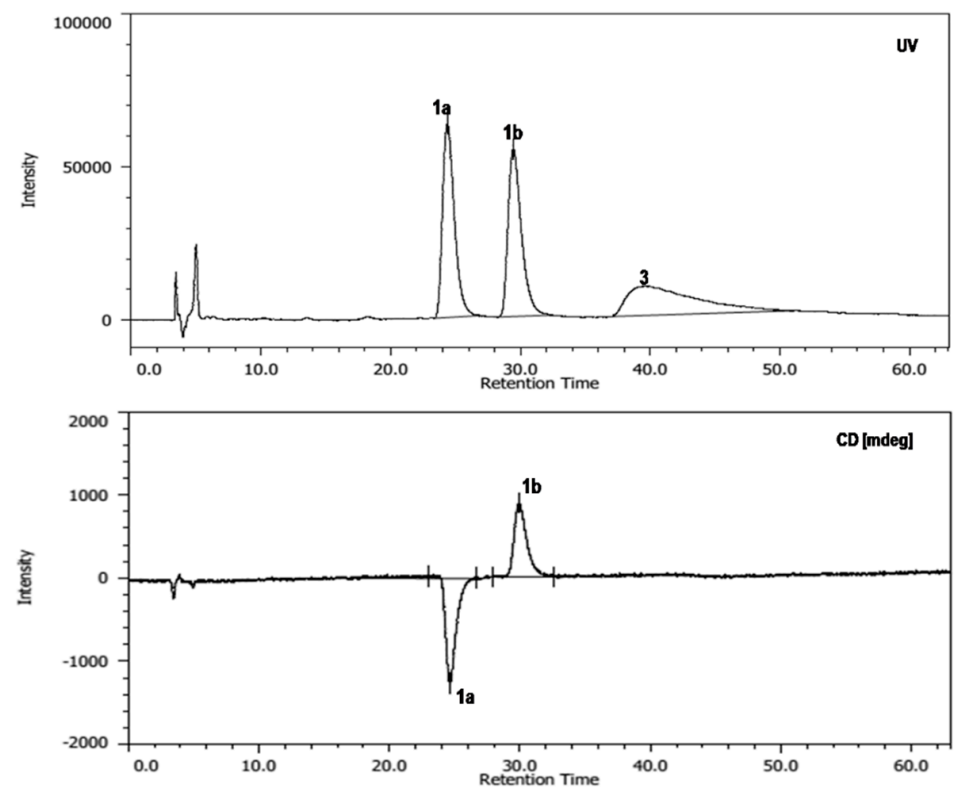

(a)
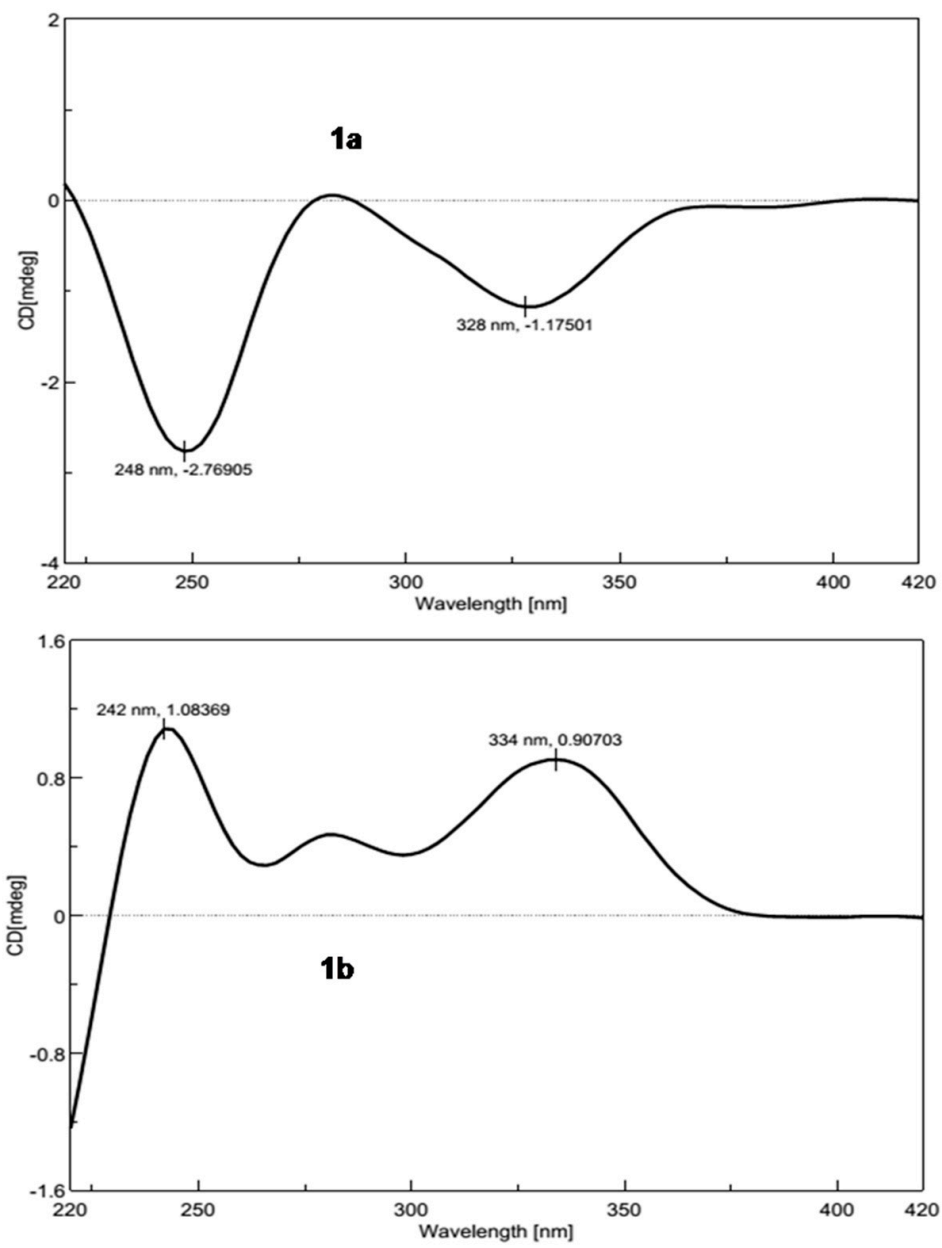

(b)

Figure 3. (a) HPLC-CD chromatogram of sporulosol (1) using a CHIRALPAK AD-H column $(4.6 \times 250 \mathrm{~mm}$; $10 \%$ 2-Propanol in Hexane for $63 \mathrm{~min} ; 1.0 \mathrm{~mL} / \mathrm{min})$; (b) HPLC-CD spectra of $\left(1^{\prime} S\right)$-sporulosol (1a) and (1'R)-sporulosol (1b). 
The molecular formula of 2 was determined to be $\mathrm{C}_{15} \mathrm{H}_{12} \mathrm{O}_{6}$ by HRESIMS. Analysis of the ${ }^{1} \mathrm{H}$ and ${ }^{13} \mathrm{C}$ NMR data of 2 (Table 1 ) revealed structural features similar to the known compound graphislactone A (3) [23], except that the 9-OMe signal disappeared, which was verified by interpretation of the 2D NMR data. Compound 2 was the first naturally occurring 4,7,9-trihydroxy-3methoxy-1-methyl-6H-benzo[c]chromen-6-one [32], and its NMR data have yet to be reported. Compounds 3-5 were readily identified as graphislactone A (3) [23], 7,9-dihydroxy-3-methoxy-1methyl-6H-benzo[c]chromen-6-one (4) [33], and enalin A (5) [26] by comparison of their NMR and MS data with those reported.

To verify that 1 was authentic natural product, a portion of the EtOAc extract freshly prepared from the freeze-dried fermented liquid substrate was subjected to HPLC-MS analysis using HPLC-grade $\mathrm{H}_{2} \mathrm{O}$ and $\mathrm{CH}_{3} \mathrm{CN}$ as solvents. Compound 1 was identified on the HPLC-MS chromatogram of the crude extract by comparison of its retention time and ESIMS data with an authentic sample (Figure S10), indicating that $\mathbf{1}$ is indeed a naturally occurring metabolite.

Compounds 1-4 were tested for cytotoxicity against a panel of five human tumor cell lines: HeLa, T24, A549, HCT116, and SH-SY5Y (Table 2). Compounds 1 and 4 showed modest cytotoxicity to T24 cells, with $\mathrm{IC}_{50}$ values of 18.2 and $4.5 \mu \mathrm{M}$, respectively (the positive control cisplatin showed an $\mathrm{IC}_{50}$ value of $\left.10.9 \mu \mathrm{M}\right)$. Compound 4 was also cytotoxic to Hela cells, showing an $\mathrm{IC}_{50}$ value of $5.4 \mu \mathrm{M}$ (the positive control cisplatin showed an $\mathrm{IC}_{50}$ value of $8.7 \mu \mathrm{M}$ ).

Table 2. Cytotoxicity of compounds 1-4.

\begin{tabular}{cccccc}
\hline \multirow{2}{*}{ Compound } & \multicolumn{5}{c}{ IC $_{\mathbf{5 0}}(\boldsymbol{\mu M})$} \\
\cline { 2 - 6 } & HeLa & T24 & A549 & HCT116 & SH-SY5Y \\
\hline $\mathbf{1}$ & $31.8 \pm 0.2$ & $18.2 \pm 5.3$ & $23.1 \pm 2.9$ & $50.1 \pm 7.0$ & $>50$ \\
$\mathbf{2}$ & $11.7 \pm 0.7$ & $22.8 \pm 1.7$ & $25.1 \pm 1.8$ & $81.5 \pm 3.4$ & $41.5 \pm 2.0$ \\
$\mathbf{3}$ & $>50$ & $77.8 \pm 8.0$ & $>50$ & $>50$ & $71.7 \pm 3.2$ \\
$\mathbf{4}$ & $5.4 \pm 0.1$ & $4.5 \pm 0.4$ & $93.7 \pm 5.6$ & $20.9 \pm 2.6$ & $38.8 \pm 4.9$ \\
cisplatin & $8.7 \pm 0.3$ & $10.9 \pm 0.7$ & $17.0 \pm 0.5$ & $19.9 \pm 0.7$ & $11.2 \pm 2.0$ \\
\hline
\end{tabular}

Although sporulosol (1) is a ketal derived from two known metabolites, it is the first example of such a ketal originating from the $6 \mathrm{H}$-benzo[c]chromen-6-one and benzofuranone moieties, representing a new type of chemical structure. The presence of such a ketal moiety generated two enantiomers racemized constantly even right after chiral resolution. In addition, the plausible biosynthetic precursor was identified as a racemic mixture, too. The proposed precursors and the reaction cascades leading to the generation of $\mathbf{1}$ are illustrated in Scheme 1.

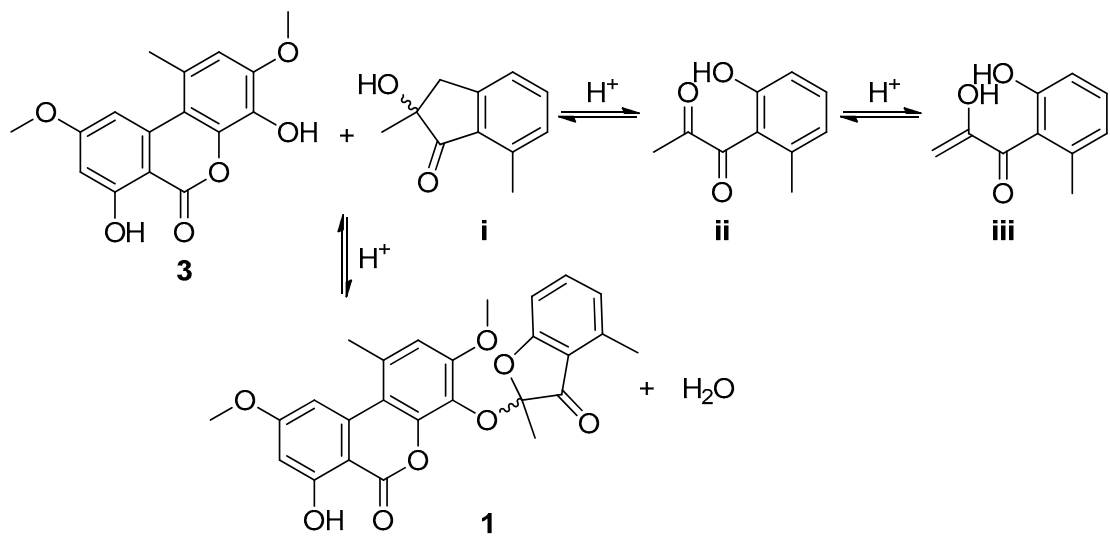

Scheme 1. Plausible biosynthetic pathways for sporulosol (1). 


\section{Materials and Methods}

\subsection{General Experimental Procedures}

An Analytical Automatic Polarimeter (Rodolph Research) was used to record optical rotations of the isolated compounds, and a Shimadzu Biospec-1601 spectrophotometer was used to measure the ultraviolet (UV) spectra. A Nicolet Magna-IR 750 spectrophotometer was used to record the infrared (IR) spectra. Nuclear magnetic resonance (NMR) spectra were recorded on Inova-400 and Inova-600 spectrometers using TMS as an internal standard. The HMBC and HMQC experiments were optimized for 8.0 and $145.0 \mathrm{~Hz}$, respectively. Electrospray ionization mass spectrometry (ESIMS) and high-resolution mass spectrometry (HRMS) data were measured on an Agilent accurate mass quadrupole time-of-flight LC/MS G6550 instrument. High-performance liquid chromatography-circular dichroism (HPLC-CD) chromatograms were recorded on a JASCO LC 2000-CD 2095 instrument. All HPLC analysis and separation were performed using an Agilent 1260 instrument (Agilent, Santa Clara, CA, USA) equipped with a variable-wavelength UV detector.

\subsection{Fungal Material}

The strain P. sporulosum Verkley was isolated from the soil samples that were collected at Poyang Lake, Jiangxi Province, P. R. China, in December 2010. The fungus was identified by morphological observation and sequence (Genbank Accession No. JX077030) analyses of the ITS region of the rDNA. The identified P. sporulosum strain was cultured on Potato Dextrose Agar (PDA) at room temperature for 10 days, and the resulting agar plugs were cut into small pieces $\left(0.5 \times 0.5 \times 0.5 \mathrm{~cm}^{3}\right)$ under aseptic conditions. Fifteen pieces were inoculated into three $250 \mathrm{~mL}$ Erlenmeyer flasks, each containing $50 \mathrm{~mL}$ medium $(0.4 \%$ glucose, $1 \%$ malt extract, and $0.4 \%$ yeast extract; $\mathrm{pH}$ 6.5), which were then incubated at room temperature on an orbital shaker at $170 \mathrm{rpm}$ for 5 days to prepare the seed culture. The fermentation was carried out in 24 Fernbach flasks of $500 \mathrm{~mL}$, each containing $5.0 \mathrm{~mL}$ seed culture and $200 \mathrm{~mL}$ synthetic dropout medium (2\% malt extract, 6\% dextrin, $0.7 \%$ peptone form fish, $0.7 \%$ cottonseed flour, $0.25 \% \mathrm{MgSO}_{4} \cdot 7 \mathrm{H}_{2} \mathrm{O}, 0.25 \% \mathrm{CaCO}_{3}, 0.1 \% \mathrm{FeSO}_{4} \cdot 7 \mathrm{H}_{2} \mathrm{O}$, and $0.001 \% \mathrm{ZnSO}_{4} \cdot 7 \mathrm{H}_{2} \mathrm{O}$ ), and incubated at $25^{\circ} \mathrm{C}$ on a rotary shaker at $170 \mathrm{rpm}$ for 30 days.

\subsection{Extraction and Isolation}

The fermented culture was extracted repeatedly with ethyl acetate (EtOAc; $4 \times 4.8 \mathrm{~L}$ ), yielding $5.0 \mathrm{~g}$ crude extract upon removal of the organic solvent under vacuum. Subsequently, the crude extract was fractionated by vacuum liquid chromatography on silica gel with gradient elution of petroleum ether (PE)-EtOAc. The fractions eluted with 88:12-82:18 PE-EtOAc were combined (338.4 mg) and separated by Sephadex LH-20 column chromatography (CC; $1: 1 \mathrm{MeOH}-\mathrm{CH}_{2} \mathrm{Cl}_{2}$ ). The subfraction $(119.5 \mathrm{mg}$ ) was purified by reversed-phase HPLC (Agilent Zorbax SB-C 18 column; $5 \mu \mathrm{m} ; 9.4 \times 250 \mathrm{~mm}$; $45 \% \mathrm{MeOH}$ in $\mathrm{H}_{2} \mathrm{O}$ for $38 \mathrm{~min} ; 2 \mathrm{~mL} / \mathrm{min}$ ) to afford $5\left(4.0 \mathrm{mg}, t_{\mathrm{R}} 21.0 \mathrm{~min}\right)$, and the resulting fraction eluted with $100 \% \mathrm{MeOH}$ was further purified by RP HPLC (74\% $\mathrm{MeOH}$ in $\mathrm{H}_{2} \mathrm{O}$ for $\left.25 \mathrm{~min} ; 2 \mathrm{~mL} / \mathrm{min}\right)$ to afford $4\left(1.0 \mathrm{mg}, t_{\mathrm{R}} 22.0 \mathrm{~min}\right)$. The fractions eluted with 80:20-78:22 PE-EtOAc were combined (445.0 mg) and separated by medium-pressure C18 RP silica gel CC using $\mathrm{MeOH}-\mathrm{H}_{2} \mathrm{O}$ gradient elution (20-100\%). Purification of the subfraction (68.9 mg) eluted with $80: 20 \mathrm{MeOH}-\mathrm{H}_{2} \mathrm{O}$ by $\mathrm{HPLC}$ (70\% MeOH in $\mathrm{H}_{2} \mathrm{O}$ for $15 \mathrm{~min}$, followed by $82 \% \mathrm{MeOH}$ in $\mathrm{H}_{2} \mathrm{O}$ for $30 \mathrm{~min} ; 2 \mathrm{~mL} / \mathrm{min}$ ) yielded 3 $\left(3.0 \mathrm{mg}, t_{\mathrm{R}} 16.5 \mathrm{~min}\right)$ and $1\left(4.0 \mathrm{mg}, t_{\mathrm{R}} 41.0 \mathrm{~min}\right)$. The fractions eluted with 67:33-60:40 PE-EtOAc were combined $(1.0 \mathrm{~g})$ and further separated by C18 RP silica gel CC eluting with $20-100 \% \mathrm{MeOH}-\mathrm{H}_{2} \mathrm{O}$. The subfractions eluted with 25:75-35:65 MeOH- $\mathrm{H}_{2} \mathrm{O}$ were combined (430.2 $\mathrm{mg}$ ), separated by Sephadex LH-20 CC (1:1 MeOH- $\left.\mathrm{CH}_{2} \mathrm{Cl}_{2}\right)$, and purified by RP HPLC (55\% $\mathrm{MeOH}$ in $\mathrm{H}_{2} \mathrm{O}$ for $\left.40 \mathrm{~min} ; 2 \mathrm{~mL} / \mathrm{min}\right)$ to afford $2\left(3.0 \mathrm{mg}, t_{R} 37.0 \mathrm{~min}\right)$. 


\subsection{Sporulosol (1)}

Sporulosol (1), colorless needles; $[\alpha]_{\mathrm{D}}^{25}+1.0\left(\right.$ c 0.10, MeOH); m.p. $130-132{ }^{\circ} \mathrm{C} ; \mathrm{UV}(\mathrm{MeOH}) \lambda_{\max }$ (log ع) 340 (3.57) nm; IR (neat) $v_{\max }$ 3555, 2997, 2848, 1726, 1673, 1444, 1233, 1203, 1134 1078, 929, $795 \mathrm{~cm}^{-1}$; for ${ }^{1} \mathrm{H},{ }^{13} \mathrm{C}$, and HMBC NMR data, see Table 1; HRESIMS $\mathrm{m} / z 463.1385[\mathrm{M}+\mathrm{H}]^{+}$(calcd. for $\left.\mathrm{C}_{26} \mathrm{H}_{22} \mathrm{O}_{8}, 463.1387\right)$.

X-ray Structure Analysis of 1 [34]. X-ray diffraction intensities were recorded with an Oxford

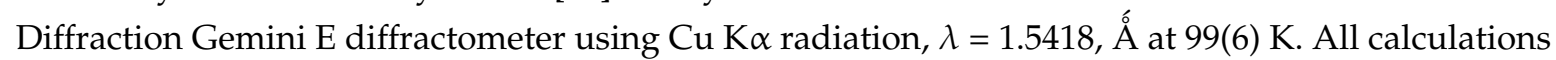
were carried out using SHELXL-97 [35] and refined using full-matrix least-squares difference Fourier techniques. The Siemens Area Detector Absorption Program (SADABS) [36] was used to determine absorption corrections. The colorless crystal of 1 was obtained in acetone- $\mathrm{H}_{2} \mathrm{O}$ (30:1). Altogether, 4128 independent reflections were collected from the 10,139 measurements, yielding $R_{1}=0.0482$ and $w R_{2}=0.1208[I>2 \sigma(I)]$. Crystal data: colorless crystal $(0.20 \times 0.18 \times 0.04 \mathrm{~mm}) ; \mathrm{C}_{26} \mathrm{H}_{22} \mathrm{O}_{8}$, $M=471.00$, space group C2/c; monoclinic crystal; unit cell dimensions $a=32.3086(15) \AA$

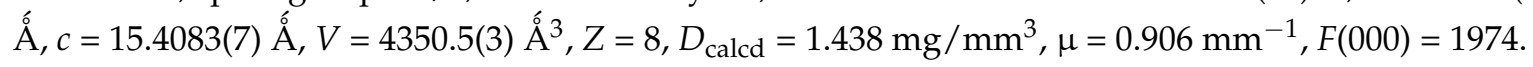

\subsection{4,7,9-Trihydroxy-3-methoxy-1-methyl-6H-benzo[c]chromen-6-one (2)}

4,7,9-trihydroxy-3-methoxy-1-methyl-6H-benzo[c]chromen-6-one (2), white powder; UV (acetone) $\lambda_{\max }(\log \varepsilon) 340(2.20) \mathrm{nm}$; IR (neat) $v_{\max } 3458,2980,2848,2158,1673,1604,1397,1230,1197,1120$, $798 \mathrm{~cm}^{-1}$; for ${ }^{1} \mathrm{H}$ and ${ }^{13} \mathrm{C}$ NMR data, see Table 1; HRESIMS $m / z 289.0705[\mathrm{M}+\mathrm{H}]^{+}$(calcd. for $\left.\mathrm{C}_{15} \mathrm{H}_{12} \mathrm{O}_{6}, 289.0707\right)$.

\subsection{MTT Assay}

The cytotoxicity of compounds 1-4 was evaluated with the MTT assay [37]. The cell lines at a density of $(2-5) \times 10^{3}$ cells/well were seeded in 96-well plates and allowed to adhere for $24 \mathrm{~h}$. Subsequently, compounds 1-4 and cisplatin were added at appropriate concentrations and incubated with cells at $37^{\circ} \mathrm{C}$ for $48 \mathrm{~h}$ in a $5 \% \mathrm{CO}_{2}$-containing incubator. Finally, $20 \mu \mathrm{L}$ of MTS (Promega) was added to each well in the dark to assess the proliferation after $90 \mathrm{~min}$ incubation at $37^{\circ} \mathrm{C}$. The optical density was recorded on a microplate reader at $490 \mathrm{~nm}$. All tests were run in triplicate.

Supplementary Materials: The supplementary materials are available online. NMR spectra of Compounds 1 and 2 (Figures S1-S6), Figure S7: HPLC chromatogram of sporulosol (1) using a CHIRALPAK AD-H column; Figure S8: HPLC chromatogram of enalin A (5) using a CHIRALPAK AD-H column title; Figure S9: HPLC-CD chromatogram of enalin A (5) using a CHIRALPAK AD-H column title; Figure S10: HPLC-MS analysis of the crude extract.

Author Contributions: Y.C. and F.R. conceived and designed the experiments; C.Z., P.F., Y.Z. performed the experiments and analyzed the data; X.L. contributed materials; C.Z. and F.R. wrote the paper.

Acknowledgments: We gratefully acknowledge financial support from the National Natural Science Foundation of China (81402832) and the National Program of Drug Research and Development (2012ZX09301-003).

Conflicts of Interest: The authors declare no conflict of interest.

\section{References and Notes}

1. Schueffler, A.; Anke, T. Fungal natural products in research and development. Nat. Prod. Rep. 2014, 31, 1425-1448. [CrossRef] [PubMed]

2. Bao, Y.; Chen, G.; Wu, Y.; Li, X.; Hu, D.; Liu, X.; Li, X.; Yao, X.; Gao, H. Stachybisbins A and B, the first cases of seco-bisabosquals from Stachybotrys bisbyi. Fitoterapia 2015, 105, 151-155. [CrossRef] [PubMed]

3. Zhang, L.; Feng, B.; Sun, Y.; Wu, H.; Li, S.; Liu, B.; Liu, F.; Zhang, W.; Chen, G.; Bai, J.; et al. Flaviphenalenones A-C, three new phenalenone derivatives from the fungus Aspergillus flavipes PJ03-11. Tetrahedron Lett. 2016, 57, 645-649. [CrossRef] 
4. Zhang, L.; Feng, B.; Zhao, Y.; Sun, Y.; Liu, B.; Liu, F.; Chen, G.; Bai, J.; Hua, H.; Wang, H.; et al. Polyketide butenolide, diphenyl ether, and benzophenone derivatives from the fungus Aspergillus flavipes PJ03-11. Bioorg. Med. Chem. Lett. 2016, 26, 346-350. [CrossRef] [PubMed]

5. Tian, J.; Li, P.; Li, X.; Sun, P.; Gao, H.; Liu, X.; Huang, P.; Tang, J.; Yao, X. New antibacterial isocoumarin glycosides from a wetland soil derived fungal strain Metarhizium anisopliae. Bioorg. Med. Chem. Lett. 2016, 26, 1391-1396. [CrossRef] [PubMed]

6. Verkley, G.J.; da Silva, M.; Wicklow, D.T.; Crous, P.W. Paraconiothyrium, a new genus to accommodate the mycoparasite Coniothyrium minitans, anamorphs of Paraphaeosphaeria, and four new species. Stud. Mycol. 2004, 50, 323-335.

7. Tsuda, M.; Mugishima, T.; Komatsu, K.; Sone, T.; Tanaka, M.; Mikami, Y.; Kobayashi, J. Modiolides A and B, two new 10-membered macrolides from a marine-derived fungus. J. Nat. Prod. 2003, 66, 412-415. [CrossRef] [PubMed]

8. Mohamed, I.E.; Kehraus, S.; Krick, A.; König, G.M.; Kelter, G.; Maier, A.; Fiebig, H.H.; Kalesse, M.; Malek, N.P.; Gross, H. Mode of action of epoxyphomalins A and B and characterization of related metabolites from the marine-derived fungus Paraconiothyrium sp. J. Nat. Prod. 2010, 73, 2053-2056. [CrossRef] [PubMed]

9. Shiono, Y.; Kikuchi, M.; Koseki, T.; Murayama, T.; Kwon, E.; Aburai, N.; Kimura, K. Isopimarane diterpene glycosides, isolated from endophytic fungus Paraconiothyrium sp. MY-42. Phytochemistry 2011, 72, 1400-1405. [CrossRef] [PubMed]

10. Almeida, C.; Aouad, N.E.; Martín, J.; Pérez-Victoria, I.; González-Menéndez, V.; Platas, G.; de la Cruz, M.; Monteiro, M.C.; de Pedro, N.; Bills, G.F.; et al. Graminin B, a furanone from the fungus Paraconiothyrium sp. J. Antibiot. 2014, 67, 421-423. [CrossRef] [PubMed]

11. Amand, S.; Vallet, M.; Guedon, L.; Genta-Jouve, G.; Wien, F.; Mann, S.; Dupont, J.; Prado, S.; Nay, B. A reactive eremophilane and its antibacterial $2(1 H)$-naphthalenone rearrangement product, witnesses of a microbial chemical warfare. Org. Lett. 2017, 19, 4038-4041. [CrossRef] [PubMed]

12. Soliman, S.S.; Tsao, R.; Raizada, M.N. Chemical inhibitors suggest endophytic fungal paclitaxel is derived from both mevalonate and non-mevalonate-like pathways. J. Nat. Prod. 2011, 74, 2497-2504. [CrossRef] [PubMed]

13. Somjaipeng, S.; Medina, A.; Kwaśna, H.; Ordaz Ortiz, J.; Magan, N. Isolation, identification, and ecology of growth and taxol production by an endophytic strain of Paraconithyrium variabile from English yew trees (Taxus baccata). Fungal Biol. 2015, 119, 1022-1031. [CrossRef] [PubMed]

14. De Gusmño, N.B.; Kaouadji, M.; Steiman, R.; Seigle-murandi, F.; Ulrichc, J. Coniothyriol, an uncommon polyketide from Coniothyrium sporulosum. Nat. Prod. Lett. 1993, 2, 287-292. [CrossRef]

15. Guiraud, P.; Steiman, R.; Seigle-murandi, F.; de Gusmño, N.B. Antimicrobial and antitumor activities of mycosporulone. J. Nat. Prod. 1999, 62, 1222-1224. [CrossRef] [PubMed]

16. Zhang, L.; Feng, B.; Chen, G.; Li, S.; Sun, Y.; Wu, H.; Bai, J.; Hua, H.; Wang, H.; Pei, Y. Sporulaminals A and B: A pair of unusual epimeric spiroaminal derivatives from a marine-derived fungus Paraconiothyrium sporulosum YK-03. RSC Adv. 2016, 6, 42361-42366. [CrossRef]

17. Zhang, L.; Li, S.; Wu, H.; Chen, G.; Li, L.; Bai, J.; Hua, H.; Wang, H.; Pei, Y. 3,4-Dihydroisocoumarin derivatives from the marine-derived fungus Paraconiothyrium sporulosum YK-03. Phytochem. Lett. 2017, 20, 200-203. [CrossRef]

18. Liu, L.; Gao, H.; Chen, X.; Cai, X.; Yang, L.; Guo, L.; Yao, X.; Che, Y. Brasilamides A-D: Sesquiterpenoids from the plant endophytic fungus Paraconiothyrium brasiliense. Eur. J. Org. Chem. 2010, 3302-3306. [CrossRef]

19. Liu, L.; Chen, X.; Li, D.; Zhang, Y.; Li, L.; Guo, L.; Cao, Y.; Che, Y. Bisabolane sesquiterpenoids from the plant endophytic fungus Paraconiothyrium brasiliense. J. Nat. Prod. 2015, 78, 746-753. [CrossRef] [PubMed]

20. Guo, Z.; Ren, F.; Che, Y.; Liu, G.; Liu, L. New bergamotane sesquiterpenoids from the plant endothytic fungus Paraconiothyrium brasiliense. Molecules 2015, 20, 14611-14620. [CrossRef] [PubMed]

21. Chen, S.; Zhang, Y.; Niu, S.; Liu, X.; Che, Y. Cytotoxic cleistanthane and cassane diterpenoids from the entomogenous fungus Paraconiothyrium hawaiiense. J. Nat. Prod. 2014, 77, 1513-1518. [CrossRef] [PubMed]

22. Chen, S.; Zhang, Y.; Zhao, C.; Ren, F.; Liu, X.; Che, Y. Hawaiinolides E-G, cytotoxic cassane and cleistanthane diterpenoids from the entomogenous fungus Paraconiothyrium hawaiiense. Fitoterapia 2014, 99, $236-242$. [CrossRef] [PubMed]

23. Tanahashi, T.; Kuroishi, M.; Kuwahara, A.; Nagakura, N.; Hamada, N. Four phenolics from the cultured lichen mycobiont of Graphis scripta var. pulverulenta. Chem. Pharm. Bull. 1997, 45, 1183-1185. [CrossRef] 
24. Machida, K.; Trifonov, L.S.; Ayer, W.A.; Lu, Z.; Laroche, A.; Huang, H.C.; Cheng, K.J.; Zantige, J.L. 3(2H)-Benzofuranones and chromanes from liquid cultures of the mycoparasitic fungus Coniothyrium minitans. Phytochemistry 2001, 58, 173-177. [CrossRef]

25. Bekker, R.; Li, X.; ElSohly, H.N.; Clark, A.M.; Brandt, E.V.; Ferreira, D. Resolution and absolute configuration of naturally occurring auronols. J. Nat. Prod. 2001, 64, 345-347. [CrossRef] [PubMed]

26. Lin, Y.; Wu, X.; Deng, Z.; Wang, J.; Zhou, S.; Vrijmoed, L.L.; Jones, E.B. The metabolites of the mangrove fungus Verruculina enalia No. 2606 from a salt lake in the Bahamas. Phytochemistry 2002, 59, 469-471. [CrossRef]

27. Strobel, G.; Ford, E.; Worapong, J.; Harper, J.K.; Arif, A.M.; Grant, D.M.; Fung, P.C.; Chau, R.M. Isopestacin, an isobenzofuranone from Pestalotiopsis microspora, possessing antifungal and antioxidant activities. Phytochemistry 2002, 60, 179-183. [CrossRef]

28. Harper, J.K.; Arif, A.M.; Ford, E.J.; Strobel, G.A.; Porco, J.A., Jr.; Tomer, D.P.; Oneill, K.L.; Heider, E.M.; Grant, D.M. Pestacin: A, 1,3-dihydro isobenzofuran from Pestalotiopsis microspora possessing antioxidant and antimycotic activities. Tetrahedron 2003, 59, 2471-2476. [CrossRef]

29. Li, E.; Jiang, L.; Guo, L.; Zhang, H.; Che, Y. Pestalachlorides A-C, antifungal metabolites from the plant endophytic fungus Pestalotiopsis adusta. Bioorg. Med. Chem. 2008, 16, 7894-7899. [CrossRef] [PubMed]

30. Li, E.; Zhang, F.; Niu, S.; Liu, X.; Liu, G.; Che, Y. A spiro[chroman-3,7'-isochromene]-4, $6^{\prime}\left(8^{\prime} H\right)$-dione from the Cordyceps-colonizing fungus Fimetariella sp. Org. Lett. 2012, 14, 3320-3323. [CrossRef] [PubMed]

31. Sun, T.; Kuang, R.; Chen, G.; Qin, S.; Wang, C.; Hu, D.; Wu, B.; Liu, X.; Yao, X.; Gao, H. Three pairs of new isopentenyl dibenzo[b,e]oxepinone enantiomers from Talaromyces flavus, a wetland soil-derived fungus. Molecules 2016, 21, 1184-1195. [CrossRef] [PubMed]

32. Dellafiora, L.; Dall'Asta, C.; Cruciani, G.; Galaverna, G.; Cozzini, P. Molecular modelling approach to evaluate poisoning of topoisomerase I by alternariol derivatives. Food Chem. 2015, 189, 93-101. [CrossRef] [PubMed]

33. Harris, T.M.; Hay, J.V. Biogenetically modeled syntheses of heptaacetate metabolites alternariol and lichexanthone. J. Am. Chem. Soc. 1977, 99, 1631-1637. [CrossRef]

34. Crystallographic data for 1 have been deposited with the Cambridge Crystallographic Data Centre (deposition number CCDC 1585447, accessed on 14/11/2017). Copies of the data can be obtained, free of charge, on application to the director, CCDC 12 Union Road, Cambridge CB2 1EZ, UK (fax: +44 1223336033 or email: deposit@ccdc.cam.ac.uk).

35. Sheldrick, G.M. SHELXL-97, Program for X-ray Crystal Structure Solution and Refinement; University of Göttingen: Göttingen, Germany, 1997.

36. Sheldrick, G.M. SADABS, Program for Empirical Absorption Correction of Area Detector Data; University of Göttingen: Göttingen, Germany, 1999.

37. Zhang, N.; Chen, Y.; Jiang, R.; Li, E.; Chen, X.; Xi, Z.; Guo, Y.; Liu, X.; Zhou, Y.; Che, Y.; et al. PARP and RIP 1 are required for autophagy induced by $11^{\prime}$-deoxyverticillin $\mathrm{A}$, which precedes caspase-dependent apoptosis. Autophagy 2011, 7, 598-612. [CrossRef] [PubMed]

Sample Availability: Samples of the compounds 1-5 are available from the authors.

(C) 2018 by the authors. Licensee MDPI, Basel, Switzerland. This article is an open access article distributed under the terms and conditions of the Creative Commons Attribution (CC BY) license (http:/ / creativecommons.org/licenses/by/4.0/). 